\title{
Karl Barth's understanding of Christian Baptism as a basis for a conversation on the praxis of Sacraments in the Uniting Reformed Church in Southern Africa
}

\begin{abstract}
Authors:
Rothney S. Tshaka

Tshepo Lephakga

\section{Affiliations:}

${ }^{1}$ Department of Philosophy, Practical and Systematic Theology, University of South Africa, South Africa

\section{Correspondence to:} Rothney Tshaka

Email:

tshakrs@unisa.ac.za

Postal address:

Samuel Pauw Building, Room 4-35, Department Philosophy, Practical and Systematic Theology, Preller Street, Muckleneuk, Pretoria 0003, South Africa
\end{abstract}

\section{Dates:}

Received: 07 Sept. 2012

Accepted: 02 Feb. 2013

Published: 07 May 2013

How to cite this article: Tshaka, R.S. \& Lephakga, T., 2013, 'Karl Barth's understanding of Christian Baptism as a basis for a conversation on the praxis of Sacraments in the Uniting Reformed Church in Southern Africa', HTS Teologiese Studies/ Theological Studies 69(1), Art. \#1330, 8 pages. http:// dx.doi.org/10.4102/hts v69i1.1330

\section{Copyright:}

(C) 2013. The Authors. Licensee: AOSIS OpenJournals. This work is licensed under the Creative Commons Attribution License.

Read online:
This article is an initial attempt to bring the subject of baptism and to a lesser extent infant baptism in particular, as demonstrated in Karl Barth's Church Dogmatics, into a conversation with the practice of this phenomenon in African Reformed churches in South Africa, specifically the Uniting Reformed Church in Southern Africa (URCSA). Whilst the Roman Catholic and Reformed traditions regarding the sacraments differ significantly in the understanding of this subject, this article will examine Barth's understanding of baptism. This is done by critically examining key themes in his Church Dogmatics. The praxis of the sacraments and especially that of baptism continue to be a praxis that is highly venerated in African Reformed theological circles. This is so because it is believed that symbolism continues to occupy centre stage in African Reformed churches. In a sense therefore it seems that the African Reformed Christian leans more towards a Roman Catholic understanding of this sacrament. Is that perhaps true? Essentially this conversation will explore the relationship of faith to baptism and how this impacts on infant baptism for instance.

\section{A brief overview of Karl Barth's understanding of Christian Baptism}

Karl Barth was unquestionably one of the greatest Reformed theologians of the previous century a view held even by Roman Catholicism through its papacy, and reflected in the number of books that continue to be published annually on the theological reflections of this important Doctor ${ }^{1}$ of the Church. However, it cannot be denied that his views about baptism and infant baptism in particular have created more divisions within Reformed circles than they have established unity. For Christians of African descent who equally insists on their Reformed affinity to the Christian faith, the question of baptism is of particular importance. ${ }^{2}$ It is important because Africans identify readily with symbols and rituals. Yet the fact that these Christians insist on being a member of a Reformed church, has necessitated an examination of the theological reflections of Barth on the question of baptism.

It might be strange to some ${ }^{3}$ that we link Barth to Africa, but it is true that he once 'wondered whether he might perhaps be a herald of awakening Africa, which one day will put us in its pockets lock, stock and barrel' (Busch 1976:25). Perhaps it was a bit arrogant of him to claim that he might be a herald for the African Renaissance, but he was correct that Africans will wrestle with him as they try to make theological sense of God in Africa today (Smit 1992:88). ${ }^{4}$

We agree with Mangina that Barth's (2004) ethics in his Church Dogmatics IV/4 (henceforth referred to only as CD) is organised on a Trinitarian principle; the command of God encounters

1.It is a known fact that Karl Barth never attained a PhD qualification. For some, that qualification might suggest that such a person does not qualify to be called a Doctor of the Church. Barth himself felt inadequate as a teacher for not having such a qualification. It is my opinion that one of the reasons why Barth worked so hard academically was to make up for that inadequacy. When he moved from Safinwil to occupy the professorial chair of theology in Göttingen he felt the need to acquire skills to mount the academic donkey. Cf E. Busch (1976:127)

2.By Christians of African descent, I refer to those Christians who insist on their double identity as Africans and Reformed Christians. In the Uniting Reformed Church in South Africa consistent moves to identify with being African and Reformed is happening on a large scale. One of the Seminaries of this church based in Pretoria is called the Northern Theological Seminary and its motto reads an African Reformed praxis.

3.Any attempt to integrate being Africa and Reformed is something that seems to be somewhat frowned upon. It is interesting to note that this frowning upon comes from the very Africans who see the West as having saved Africa from her savagery. That is understand under andable the man South, it cannot be allow. for her to asserthrself Bart not deal with Africa as a phenomenon simply because, Barth as a child of his day, was concerned with issues that plagued him in his particular context at the time.

4.Dirkie Smit rightly argues that Karl Barth has always been read differently by different people who saw him as an important conversational partner. He thus refers to the many South African Reformed theologians who were influenced by Barth, Cf. Smit (1992:88-110). I do however want to highlight some African Reformed theologians who took Barth as a serious conversational partner in their theological reflections which is spelt out in their respective doctoral dissertations. Amongst them may be counted the likes of Takatso Mofokeng (1983); Dolamo (1993); see also my own dissertation, Tshaka (2010). 
us as the Creator's address to creatures, as the Reconciler's address to forgiven sinners and as the Redeemer's address to God's children and heirs. It is for this reason that each very important section on his CD ends with a section on ethics (Mangina 2001:170).

Barth remained aware of the fact that baptism occupies a central position in the Reformed church, thus he was not unaware of the fact that fiddling especially with the phenomenon of infant baptism would cause some major ramblings. It was this knowledge that led him to predict the following in the preface to his last major theological writing:

I foresee that this book, which by human judgment will be my last major publication, will leave me in the theological and ecclesiastical isolation which has been my lot for almost fifty years. I am thus about to make a poor exit with it. So be it! (Barth 2004:xii)

Is his work on baptism (Barth 2004) indeed his poor exit? First as indicated earlier, the typical writing style of Barth was to deal with a major question and then end with the ethical reflections that dealt with the subject. It is for this reason that his work, The Christian Life (Barth 1981), which was published posthumously must be read in line with this section of the CD IV / 4 (Barth 2004) which deals with baptism as the foundation of Christian life.

Nevertheless, to return to our question whether this was in fact a poor exit, we shall commence by looking at Barth's reflections on this subject in earlier writings. One of Karl Barth's initial reflections on baptism is contained in a lecture that he gave at a gathering of Swiss theological students on 07 May, 1943 at Gwatt am Thunerse and which was subsequently printed under the title, Die Kirchliche Lehre von der Taufe [The Teaching of the Church regarding Baptism] (Barth 1959:6). In the mentioned work, he argues essentially that:

Christian baptism is in essence the representation of man's [sic] response through his [sic] participation by means of the power of the Holy Spirit in the death and resurrection of Jesus Christ, and therewith the representation of man's [sic] association with Christ, with the covenant of grace which is concluded and realised in Him [sic], and with the fellowship of His [sic] Church. (Barth 1959:9)

Busch argues that in that lecture Barth explained that the sacrament of baptism did not bring about the salvation of man, but attested his salvation by the symbolic representation of his renewal in Christ (Barth 2004:320). Schüssler Fiorenza and Galvin (2011:510) refer to this as 'baptism as union with Christ and partnership in the covenant.'

Already in this lecture we see that for Barth (1959), baptism is not some free standing phenomenon which is dependent on itself, but is a phenomenon that has its command from the very head of the Christian church. Thus he argues that:

what baptism portrays, according to the basic passage in Romans vi $1 \mathrm{f}$, is a supremely critical happening, a real event whose light and shade fall upon the candidate in the course of his [sic] baptism. (p. 11)
At this time Barth had still maintained and defended the sacramental understanding of baptism (Barth 2004:x).

In a typical Barth manner, he would come to change his mind a few years later about some of the issues mentioned in this article. Barth (2004) maintains the following about the mentioned work, in his CD IV /4:

some years ago I composed and published a little work on this theme, 'the teaching of the church regarding baptism (1948). In the meantime, however, I have come to rather a different view of the matter. (p. ix)

That does not justify that his views as expressed in that work must be dismissed altogether, because as one will observe when reading his later works closely, Barth did not depart too radically from that said work, except to reject the sacramental basis of baptism. In fact, it is our opinion that the manner in which he reflects on baptism in itself would be one of the reasons that he would distance himself later from infant baptism. For him already in the mentioned earlier work, baptism requires a reaction or a response for one's baptism to be validated. It is for this very reason that we engage his latter views on baptism together with his earlier views on the matter. Put differently, for Barth the request for baptism is invariably followed by a response from the person who requested to be baptised. This response or confession of the person who seeks to be reconciled with God is a recurring theme throughout his theological career.

It is for this very reason that it has been argued elsewhere that Barth approached his theology in a confessional manner - in other words, constantly seeking a way for the Christian, who happens to be human, to respond to the faithfulness of a God who is not dependant on the response of this Christian, yet out of grace seeks to be in communion with him and/ or her. ${ }^{5}$ Thus a confessional approach to theology is one that concedes that our reflections about God can only be temporal. Barth argues that the Greek and German words which refer to baptism, suggest that a human being or object is being completely immersed in water and then withdrawn from it again (Barth 1959:9). This analogy is significant simply because just as with circumcision, this shows the character of a direct threat to life, accompanied immediately by the corresponding deliverance and preservation (Barth 1959:9).

The very issues pointed out in the lecture given, were further developed and are contained in his Church Dogmatics (Barth 2004) in which he expands on the doctrine of reconciliation. ${ }^{6}$ It is the opinion of the author that Barth's work on baptism,

5.In his doctoral dissertation, Tshaka (2010) demonstrates this point. In explaining Barth's confessional theology he notes the presence of at least five dominant features of Barth's theological thinking: a theology aggressively anchored in the word of God (the Bible); the church is always the immediate subject of theology; theology cannot ignore the socio-economic and political context in which it is expressed; theology must witness Jesus Christ to the public; and theology is always ethical. Because he adhered to these, Barth was always able to begin at the beginning. An understanding of the dilemma posed by the compulsion to speak about God and the simultaneous inability to do so provides insight into why Barth viewed his theology as being provisional and temporary, and having only a relative authority.

6.Church Dogmatics IV/4 (Barth 2004) cited here is a work related to the work published posthumously under the title, The Christian Life, and consists of lectures published posthumously under the title, The Christian Life, and consists of lectures
from the 1959/1960 academic year on the ethics of reconciliation which would have from the $1959 / 1960$ academic year on the ethics of reconciliation which would have
formed part of the complete Church Dogmatics vol. IV/4. See for instance Mangina formed part
$(2001: 169)$. 
and specifically his work on infant baptism, is dismissed because he dared to go where only a very few dared to go. For those who we raised within the Reformed church, it is hard to imagine baptism without infant baptism. This is especially true for those Christians of African descent who insist on the double consciousness of their identity.

\section{The Holy Spirit as agent of this union of humanity with Christ}

In pondering the question of the origin of human faithfulness and its relationship to God's faithfulness, Karl Barth admits that 'even in great poverty, weakness and contradiction there exists such a thing as humankind's genuine faithfulness in relation to God's own faithfulness' (Barth 2004:3). Notwithstanding the reality of experience from which some people may claim to understand this faithfulness in relation to God's faithfulness, Barth argues that for the sake of locating the essence of this relationship, it is best that those involved in such a venture confine themselves not to experience, but to what scripture says about it (Barth 2004:3).

He starts his treatment of this matter by pointing out that any attempt to locate the reality of humankind's faithfulness to God's faithfulness anywhere other than in God is bound to offset one's determination. Humankind (to be understood in German as Mensch) is therefore not capable of faithfulness to God. Barth asserts that, 'we have to be clear that the faithfulness to God here at issue must be understood as a human act, the Christian life as the life of man' (Barth 2004:4). He goes on to raise a point fundamental to his argument:

it is important to see how humankind becomes the subject of this event, the event of faith in God, love for him [sic], of hope in humankind, a human being who wills and acts in this positive relation to him, a friend to God instead of his enemy. (p. 4)

Barth admits that as God's creation the human being has by his or her very nature his and/or her own determination, which is not destroyed or damaged by his and/or her conflict with God and his and/or her fellow human beings. Faithfulness to God is therefore pivotal, because when he and/or she is faithful to God, he and/or she is on the path to fulfil this determination. Although Barth seems to be discarding this determination as not being a factor that makes this human being a Christian, it would appear that faithfulness to God, which is enabled in the human being through God, plays a contributing factor to the human being's becoming a Christian (Barth 2004:4f.).

A human being therefore becomes a Christian only by divine judgement and on the basis of a divine possibility that wills and commences his or her Christian life. Barth explains this divine possibility with critical reference to three classical views in the history of Christian theology. In the first, he equates the divine possibility with God's power to make humankind faithful to himself, to make the human being a Christian by blessing him and/or her through an infusion of supernatural powers (Barth 2004:5). This Barth calls the Roman Catholic view.
The second view locates the possibility of God's power to be gracious to the human being by summoning him and/or her and spurring him and/or her on in the fulfilment of his and/or her natural religious and moral impulses. Barth finds this view to have been made popular by Neo-Protestantism, particularly around the end of the 17th century, and clearly a revival of ancient Pelagianism (Barth 2004:5).

The third view, which stands in contrast to popular Roman Catholicism, restricts the possibility of God's power to introduce a human being who has been judged afresh and with grace, but who is in himself and/or herself unaltered. Barth holds that this is the form which the Reformation doctrine of justification received - incorrectly, but in a way which had more than a contemporary influence - at the hands of Melanchthon, and Lutheran orthodoxy subsequently followed (Barth 2004:5).

Barth does not believe any of these three definitions developed through the course of theological history, to be adequate or to correspond to the answer that Holy Scripture gives concerning what the divine possibility really is (Barth 2004:5). He is of the view that the only adequate answer is the one that teaches us that the change which the human being undergoes derives from the freedom of the gracious God, which allows him and/or her the freedom to become what he and/or she was not and could not be before and consequently to do what he and/or she did not and could not do before, that is, to be faithful to God (Barth 2004:5f.). This now leads us to human action. Let us therefore briefly see how Barth deals with this matter.

\section{Baptism as human decision with its origin in the divine change}

Barth argues that there are two elements in the foundation of the Christian life: one is objective and the other is subjective, and there is both a correlation and a clear distinction between them. He explains these elements thus: (1) the divine change makes possible and demands human decision as conversion from unfaithfulness to faithfulness to God, and (2) the foundation of the Christian life and the existence of a human being who is faithful to God arise only because this human decision has its origin wholly and utterly in the divine change (Barth 2004:41).

It cannot strictly be argued that this view deviates from the traditional understanding of the essence of baptism, but it is necessary to realise from this description of the role of baptism and its meaning for the individual who responds to this divine change, that he and/or she lacks the capacity to respond appropriately to this gracious God. It is therefore not by chance that Barth asserts that it is only when the two elements are seen together in differentiated unity that one can comprehend them and therefore concede the role of God and the response that is envisaged from the individual (Barth 2004:41). 
Insistence on the difference between and the unity of these elements permits one to construe God's act with the necessary strictness, just as one is able to construe the human being's act with the same necessary strictness. If the action of the divine is detected from the action of humankind, for Barth it then becomes clear that baptism by the Holy Spirit does not exclude baptism with water. Fundamentally it becomes clear that baptism by the Holy Spirit demands baptism with water. We are thus introduced to the one foundational event of Christian life (Barth 2004:41).

The essence of conceding the distinct actions enables us to see that on the one hand we are faced with God's action directed at humanity, whilst on the other hand we are faced with a demand to which humanity is subjected, and in response to which humanity turns to God. We have thus to do with both a command expressed in God's gift and with the human being's obedience of faith that renders him and/or her a recipient of the divine gift (Barth 2004:41). This leads Barth to the conclusion that without this unity of the two in their distinction, there can be no Christian ethics. Christian ethics is here possible only because there is a God who commands in his grace and there is responsible action which is elicited from a human being who is grateful to this God (Barth 2004:41).

Barth holds that if in appreciation of this gift from God, this human being's acceptance of God's grace is sincere, 'it cannot remain merely contemplative, speculative or meditative, nor can it be merely verbal; it must become at once the Yes of a grateful work' (Barth 2004:42). Faith plays an essential role in this transaction. For Barth it is important that when the human being starts to believe, he and/or she must establish a fact which - no matter how improbable it might seem, or how often or severely he and/or she might later oppose it he and/or she cannot reverse (Barth 2004:43).

The person who is about to be baptised takes this first step (the decision to be baptised) as his and/or her resolution to be obedient to him and/or her who first freed him and/or her to take this first step and summoned him and/or her to it (Barth 2004:43). It is possible to deduce from this view about how one comes to this decision that ultimately the candidate who is about to be baptised does not rely on his and/or her own independent decision, but that ultimately this decision is willed by God, who summons him and/or her to this act.

Baptism takes place because the person who has come to believe in Christ requests it; therefore he and/or she does this as his and/or her own work, yet he and/or she does this in obedience to Christ. For Barth, Christian baptism is the first form of human decision which in the foundation of the Christian life corresponds to the divine change (Barth 2004:44). He is furthermore of the view that the Bible itself does not contain a doctrine of baptism as such, although a number of biblical accounts refer to this subject. Barth (2004) does not see this as cause for alarm because, he argues:
Christian baptism (although it is the first form of human decision) is taught and described as a secondary foundation of the Christian life and therefore there is no need for this to be repeated again explicitly in later writings. (p. 48)

Therefore, because it is a secondary foundation, he maintains that in faith one may, should and will accept baptism. However, he goes on to caution that one cannot believe one's baptism, or believe in it; one can only confess one's baptism. The idea that human beings can baptise themselves is just as alien to Barth as it is to the New Testament.

By an exegesis of some of the New Testament passages that make either direct or indirect reference to baptism, Barth is able to establish a basic outline of a doctrine of Christian baptism and focuses on the following three issues, namely, (1) the basis of baptism, (2) the goal of baptism and (3) the meaning of baptism. We shall now focus on these in specific detail.

\section{Karl Barth's understanding of the basis of Christian baptism}

He begins to consider the basis of baptism by asking a number of fundamental questions on the subject. Chief amongst these is: on what basis and for what reason is baptism the first step of the human decision which follows the divine change, the first concrete form of a new life act of humanity corresponding to the faithfulness of God, faithfulness to it in return and hence obedience? (Barth 2004:50).

Barth locates the simplest answer in Matthew 28:19 in the form of a baptismal command expressly uttered by Jesus Christ himself. He admits that this passage points both implicitly and explicitly to the will and command of the Man of Nazareth who was crucified on Golgotha, and was manifested as the Messiah of Israel and the Saviour of the world - his will and command is that those who would join and belong to his people should be baptised, and that his commission to his people should include the summoning to baptism and the granting of baptism to those who wish to belong to his people.

It is imperative to note, says Barth, that although this passage includes the command to baptise, it is in the first instance not a baptismal command but a missionary command. The Christ on whom all power is bestowed in heaven and on earth makes an authoritative statement in which he commands some to make apostles of all the nations (Mt 28:18-20). This passage, it must be noted, transcends the previous restriction contained in Matthew 10:5.

Because baptism was considered to be the first and decisive step which these new disciples must take, those who were already Christ's disciples were ordered in this connection to extend an invitation to be baptised and to administer this baptism to those who responded. This baptism is unique in that those commissioned to baptise were instructed to follow

7.In Matthew 10:5-6 we read that when Christ sent his twelve disciples he gave them strict instructions not to go to the Gentiles or the Samaritans, but only to the people of Israel, God's lost sheep. 
a particular formula: they were to baptise in the name of the Father and of the Son and of the Holy Spirit (Barth 2004:52).

Barth holds that since the Easter account should not be construed as a new account of the acts and sufferings of Christ, but instead as a record of the powerful working of those already accomplished, the direct command to baptise is not a new thing, but rather an explication and proclamation of the institution of baptism already effected previously in the history of Christ, namely his baptism in the River Jordan by John (Barth 2004:52). By allowing himself to be baptised by John, Christ as the head of his people was giving an instruction that they should be baptised.

The teaching of John reveals that he encouraged those who heeded him to avoid the radical change that was about to befall the nation of Israel. In submitting to baptism by John, Christ was essentially responding to John's call that they were to be baptised so as to be saved from the likely fate of this nation (see Mk 3:10, Lk 3:9). Barth is of the view that when Christ allowed himself to be baptised by John, he was confessing both God as well as the human being. Thus, with his people, he received the word of God which came to humanity through John, who had witnessed it. It is for this reason that he holds the accusation and threat which, according to the Synoptists, was directed only to the others and not to the Man of Galilee, who came with them, inappropriate (Barth 2004:67).

In summary, Barth asserts that the basis of the baptism of Jesus Christ is located in his baptism by John in the River Jordan. This account reveals the motivation which distinguishes his baptism from a custom, a traditional ceremony which is accepted and cherished because it is established and universal practice, and its motivation as a command which is given to the Christian community which it cannot evade without making itself guilty of caprice (Barth 2004:67).

\section{Karl Barth's understanding of the goal of Christian baptism}

Concerning the goal of baptism, the most important question is: what does this baptising community have in mind when the head of this community was willing to be baptised by John as it executes its function of baptising those that seek baptism? A similar question that might be asked pertaining to the candidate who seeks to be baptised, is: what does the candidate have in mind when confessing the faith of this community that he and/or she is about to join as his and/ or her own?

Karl Barth is of the view that with regard to the goal of baptism, there is no doubt that the action of those who give and receive Christian baptism, like that of John and those whom he baptised (Jesus included), is one which looks beyond itself, beyond the capacities of the participants, the power of their common action, the particular character and effect of the action. Its telos is transcendent and not immanent (Barth 2004:69). Because John acknowledges that there is one coming after him who will be baptising with the Holy Spirit, his baptism demanded a form of conversion.

\section{Karl Barth's understanding of the meaning of Christian baptism}

After considering the basis and goal of baptism, Barth argues that baptism is the meaning of the human action taken by people who are obedient to Christ and whose hope is in him. Before attempting to discuss this claim, Barth (2004) makes a critical remark concerning baptism that can not be ignored. He argues that:

the praise of baptism is not served, but is instead irreparably damaged, if the sanctity of this action is sought not in the true and distinctive thing which characterises it as a human action, but in a supposedly immanent divine work. (p. 101)

Baptism relates to the one divine work which took place in Jesus Christ, to the one divine word which was spoken by him. It is therefore not in itself a divine work and word; instead, it is the work and word of a person who had become obedient to Jesus Christ and who had put hope in him. ${ }^{9}$ It has already been pointed out that for Barth, although baptism with water is not divine in itself, it is nevertheless necessary because it takes place in light of the baptism of the Spirit and with a view to it. He states it succinctly thus:

baptism takes place in active recognition of the grace of God which justifies, sanctifies and calls. It is not itself, however, the bearer, means, or instrument of grace. Baptism responds to a mystery, the sacrament of the history of Jesus Christ, of his resurrection, of the outpouring of the Holy Spirit. It is not itself, however a mystery or a sacrament. (Barth 2004:102)

One cannot therefore be oblivious to the fact that Barth opposes the traditional view of baptism as a sacrament and therefore as something that is shrouded in mystery. Yet the reasons that he gives for deviating from this traditional understanding are worth considering. He begins by making reference to the understanding of baptism within some ecclesiastical traditions, commencing with Roman Catholicism. He rightly notes that in Roman Catholicism, baptism, like other sacraments, is considered a sign which was constituted by Christ and which is consequently used and guaranteed by him through the church's baptism. It is also understood that it is filled with divine power and that it is more profound and comprehensive than the word, for it is perceived with all the senses; it therefore symbolises and causally underlines this power.

Because a sacrament seen in this way is perceived to possess some kind of sacramental power, it then follows that a sacrament such as baptism is considered to be working ex opere operato. Therefore, although faith and obedience are both demanded and established, baptism takes place

8.1 do not feel that John Flett (2010) in his book adequately deals with the subject of Barth's understanding of the basis of Christian baptism. This is so, simply because Barth's understanding of the basis of Christian baptism. This is so, simply because and theologian, David Bosch, Flett attempts to want to force Barth to speak to a and theologian, David Bosch, Flett attempts to want to force Barth to speak to a community that, as I have pointed out earlier, being a child of his age, he has little
interest in that which happened outside of his context.

9.It is for this reason that the baptismal font was placed high, just below the pulpit for everyone to see that there is nothing magical happening during the process of baptism. 
independently of the faith, the personal orthodoxy, or the moral worthiness of either the minister or the recipient (Barth 2004:103).

Lutheran scholarship appears not to satisfy Barth either when it comes to the meaning and essence of baptism. He sees the Lutheran view on this subject as halfway between Roman Catholic teaching and Reformed teaching. The Lutheran view is that baptism, alongside the Lord's Supper, is a visible sign which is instituted by Christ and which proclaims him and is also the effective means, organ, or instrument of an invisible grace. However, he notes that Lutheranism deviates from a Roman Catholic view of sacrament in that emphasis is laid on the distinction between baptism and the written and preached Word of God.

Ample room is therefore made for the signum audibile, which resembles baptism in power and efficacy, but takes precedence over it. Whilst acknowledging the differences between the Lutheran and the Roman Catholic views of baptism, Barth concludes that ultimately baptism, or the baptismal action, is nonetheless seen in the first instance as a reflection, and more strangely, it is seen as a reflection of the anthropological analogue of the death and the resurrection of Jesus Christ, namely the death of the old person and the rising to life of the new (Barth 2004:103-104).

Barth maintains that Luther contradicted himself through the implication that the rising to the new life could be achieved with water. Luther was of the view that these things (dying to the old and rising to the new) are done by God's word, which is in and with the water, and by faith, or trust in this word of God in the water (Barth 2004:103-104). He thus points to Luther and his followers who made a clear distinction concerning faith and works; faith alone makes truth of baptism, for it is humankind's saving subjective appropriation of the promise which is offered with objective certainty. It seems therefore that without faith, the promise is given, but in vain. The idea of ex opere operato is then avoided and instead the idea of ex opere operantis is suggested, something with which Barth could live.

We now come to the Reformed view of baptism, which is here more strongly than in either Roman Catholicism or Lutheranism, considered as being merely related to the written and preached word of God, but more fundamentally subordinate to this word as an appendix. With regard to the relationship of the word to sacraments, the example given by Phillip Theron is very impressive and serves to put into perspective the way in which we really ought to understand this relationship. Theron likens sacraments to a wedding ring: on removing the ring, a married person nevertheless remains married. Likewise, the God who does not lie gives us his promise in his word, but still swears that his word is enough by giving us a sacrament. ${ }^{10}$ Therefore, compared to the word, the sacrament is an unnecessary and yet necessary

10.Phillip Theron was retired Professor of Systematic Theology at the University of Stellenbosch and my former teacher of Systematic Theology at the University
of Stellenbosch. I fondly remember him when making examples to ground his of Stellenbos
argument. luxury, just like a wedding ring. It does not save us; we are saved by Jesus Christ.

It was important for Barth to challenge the consensus that the meaning of baptism is to be sought and found in a divine action which is concealed in its administration by human beings who make use of it. He vehemently opposes the consensus that baptism is to be defined, described and explained as a mystery, and therefore charges that such a view be demythologised. In opposing the view that baptism is a mystery and therefore a sacrament, Barth set the principle that the baptism with water, which is given by the community and desired and received by the candidates, is the human action which corresponds to the divine action in the founding of the Christian life, which responds to the baptism with the Holy Spirit and cries out for it (baptism by water) (Barth 2004:105).

\section{Karl Barth's neo-Zwinglian doctrine of baptism?}

Because baptism is a human action and requires an ethical response on the part of the human being to the grace of God, it must therefore be a free act which is undertaken under no compulsion. In opposing baptism by water as a sacrament, Barth (1959) does not encourage attempts to disparage, weaken or demean the true and proper meaning of this baptism. In fact he argues that:

so far as I know, there is no teaching about Christian baptism which would directly contest the view that water baptism itself is also, and indeed primarily, to be understood as a symbol, that is, as a type and representation or according to Gregory of Nyssa, a copy of that other divine-human reality which it attest. (pp. 13-14)

Nonetheless, he remains of the view that the sacramental language that has been associated with baptism for ages ought to be defeated at once. It is for this reason that he rejects the tradition that describes the New Testament doctrine of baptism as sacrament and refers to Jean-Jacques von Allmen (in Barth 2004) who seems to have captured and defended this in this following statement:

Le baptême est essentiellement une oeuvre de Dieu - rend efficace la mort et la resurrection du Christ - insère dans le Christ crucifié et glofifié - ajoute à l'Eglise - est une nouvelle naissance - est une condition d'entrée dans le Royaume de Dieu, est une façon de sacrifier (consecrer, dédier), à Dieu ... ceux qui désormais ne veulent plus vivre pour eux-mêmes, mais pour sa gloire. (p. 107) ${ }^{11}$

For Barth, baptism as a fact is part of the church's proclamation and that is plainly a human act (Barth 1959:16). He finds it difficult to accept the traditional view that accepts baptism as mysterion. Barth rejects this view of baptism if it is standing on its own and not depending on Christ as the chief actor (Barth 1959:19). However he does not stand alone in rejecting suggestions that baptism by water is a work of 11.Jean-Jeacques von Allmen (in Barth 2004:107). The English translation of this extract by the author reads as follows: Baptism is essentially a work of God, it makes efficient the death and resurrection of Christ - it inserts our life/joins us with Christ as he has been crucified and glorified for us - enlarges the church - it is a new birth and a condition for entry into the kingdom of God. And fi standpoint of the action of the minister it is a form of sacrificing (consecrating, dedicating) to God ... those who now no longer want to live for themselves, but for his glory. 
God. Huldrych Zwingli immediately comes to mind here. Zwingli, like Barth, deviates from the traditional doctrine of baptism. In his view, this doctrine erred when it ascribed sin-expunging power to the sacrament of baptism, especially baptism by water (cf. Gäbler 1986:128).

By arguing that nothing external can purify or justify us, Zwingli therefore repudiated baptism as a means of grace. Barth embraced this argument and developed it further in his reflections about baptism. He thus agrees with Zwingli that despite the opinions of the earliest fathers, baptism by water does not cleanse or save human beings, and that human beings are saved without baptism by faith in Christ (Barth 2004:129).

Zwingli realised later that when applied to the realm of the church, the concept 'sacrament' or sacramentum leaves one with vexing problems. He noted that although it is clear that this concept has a different application in the context of the church, the word sacramentum was used in Roman law to denote a deposit which litigants had to leave at a holy place on the opening of a civil injunction and which was forfeited by the defeated party (Barth 2004:108). It was also used in the military as an oath of loyalty accompanied by an act of religious devotion. It was for this reason that in speaking about the Lord's Supper, Zwingli clung to the word 'Eucharist' and preferred to think of this act as an 'act of thanksgiving' (cf. Gäbler 1986:134). The church of the 2nd century was not particularly concerned about this, but was instead concerned about what it would mean with reference to what happens in the church, especially during the Eucharist and baptism.

Barth and Zwingli are therefore in agreement when they assert that the words sacramentum and mysterion, when used in a theological sense, refer only to an event in the world of time and space which is directly initiated and brought to pass by God alone (Barth 2004:108). That cannot therefore be said of baptism because, according to Zwingli, it was not Christ who instituted baptism, but John the Baptist, although Christ confirmed it in Matthew 28:18-20 (Barth 2004:129). Taking his cue from this claim, Barth makes three succinct observations pertaining to the exegetical task that seeks to put the problem of the meaning of baptism to rest.

Firstly, Barth notes that the act of baptism was an impressive and incisive event in the life and thinking of the early Christians. The degree to which this notion impressed them is located in the assumption that words and concepts such as water, river, pool and fountain as used by authors conjured up pictures of baptism to a greater or lesser extent (Barth 2004:111).

Secondly, it must be realised that, strictly speaking, baptism is an independent theme in the New Testament, mentioned only in the account of the baptism of Jesus Christ in the Jordan and in Matthew 28:19. Barth rejects the view that the baptismal narratives of Acts contribute to the doctrine of baptism, although he admits that they serve to emphasise the account of the astonishing progress made in proclaiming and spreading the gospel (Barth 2004:111).

Thirdly, he furthermore asserts that when the New Testament speaks either directly or indirectly of baptism, a distinction should always be made. It should be inquired whether what is said about baptism really refers to the action as such, or whether it refers to what has already here been termed the basis on the one hand and the goal on the other, that is, to the divine act of salvation and revelation which is the basis and intention of the action and which is reflected, though only reflected in it (Barth 2004:111).

\section{Barth's understanding of baptism and its implications for infant baptism}

Barth's understanding of baptism has serious implications for infant baptism. From his earliest lectures, mentioned in this article, one can already sense that viewing the act of baptism as a conscious response to the grace of God, has implications for some. In his understanding of baptism as a human activity, albeit an important one in that it reveals the ethos of those who are willed by God to respond to his faithfulness, Barth departs from the traditional decree that children of Christian parents must be baptised.

What is significant here about Barth and his views about infant baptism is that although Barth's doctrine of baptism is likened to that of Zwingli, who despite the odds is construed as one of the most passionate advocates for infant baptism, Barth in fact rejects it and therefore stands with those who were severely criticised by Zwingli and consequently the other reformers. It therefore becomes imperative to ponder whether the charge brought against Zwingli by the Anabaptists that he compromised his reforming activities by insisting that infant baptism should be administered is perhaps not without some ground.

Martin Luther's views concerning baptism and infant baptism are briefly outlined in his Small Catechism, Question 246, asks who instituted baptism (Luther 1943:170f.). He replies that God himself instituted baptism, for Christ who is God commanded his Church to baptise all nations (Mt 28:18-20). Question 251 of this catechism asks proof that infants should be baptised as well. He answers that infants should be baptised because they are included in the words 'all nations' (Mt 28:19, Ac 2:38-39). He goes on to assert the following in the second section of his answer: 'because Holy Baptism is the only means whereby infants who, too must be born again, can ordinarily be regenerated and brought to faith' (Luther 1943:173).

What should be noted here is that Luther justifies infant baptism without making reference to the covenant, which is something, used more amongst the Swiss Reformers. 
Although his repudiation of baptism as a means of grace was directed at both the Roman Catholic Church and the Lutherans, Zwingli had to find a way of dealing with infant baptism in his theological reflections.

\section{Barth's understanding of baptism and the Uniting Reformed Church in Southern Africa: A concluding note}

Did such a critical engagement with baptism and infant baptism in particular, leave Barth in the theological wilderness? The question is answered differently depending on the context in which it is posed. For younger Christians, such as those of African descent, it is important that the whole conversation about sacraments and the sacrament of baptism in particular be laid bare. This is so because the act of baptism played a significant role for social cohesion by the West in Africa, and was intended to keep the new converts and their children in compliance with the new order.

By younger Christians here, we refer specifically to those Christians to whom the Christians gospel was transported from the West. The ones to whom the authorities thought it was vital that a practise such as baptism be maintained in order to engender social cohesion. Matters such as social cohesion which essentially was a means of forcing the new converts to adhere to the dictates of the new masters of society, became much more important than the fundamental issues that are asked for by the essence of baptism. It was the missionaries in particular who played the role of ensuring that there was acquiescence from the part of the new converts, all this was done in the name of the Christian religion.

Clearly baptism in our view was very important to bring not only the mature members if this new religion to subject themselves to the rule of the new managers of society, but this was significant for their children as well. It is for this reason that infant baptism is actually seen as a half baptism which comes into effect only once the mature candidate has undergone catechumen classes and is then confirmed as a member of the church. Again one can make reference to how people in our congregations relate to infant baptism. What is meant by this is that although both baptism and the Eucharist are seen as sacraments within our church, the debate today whether children may be allowed to participate in the celebration of the Eucharist, which is promising to result into some schisms in some regional synods of the Uniting Reformed Church in Southern Africa (URCSA), attest to the fact that infant baptism, although significant for reasons that are rather not related to faith but superstition, is not as important as the Eucharist. ${ }^{12}$

The requirements of baptism as illustrated by Barth in this article seem to take second place. It is for this reason that

12.In some regional Synods of the URCSA such as Lesotho and Phororo, as well as the Synod of the North, the Eucharist is administered only to those members who are Syno are considered beyond reproach. This means that those who have been under disciplin for either falling pregnant out of wedlock, been found guilty of being drunk and so forth, are not welcomed at the Lord's table. The Eucharist is considered as yardstick that determines who is worthy and as a carrot to those who adhere to the rules governing Christian life. It is for this reason that the Eucharist given to children is vehemently being opposed.
I want to argue that a conversation about the sacraments within the African Reformed context cannot be held if it does not take into account the misconceptions about this praxis that had become entrenched in the very minds of some Reformed Christians of African descent.

It is a known fact that sacraments, and especially that of baptism, play an even more important role in the church life of these Christians. Sacraments are considered more important simply because as a ritual, they seem to represent something that is considered more tangible than the preached word. That sacraments and especially the sacrament of baptism, is considered more significant is evidenced by the fact that Christians who otherwise have no business with the church, will ask that their children be baptised. In this case, is the question of the individual's faith not a factor that must be considered? It is the view of this paper that Barth therefore helps us as we seek a platform to intentionally deliberate our being African and Reformed at the same time in light of the reformed understanding of what baptism really is.

\section{Acknowledgements Competing interests}

The authors declare that they have no financial or personal relationship(s) that may have inappropriately influenced them in writing this article.

\section{Authors' contributions}

R.S.T. (University of South Africa) was largely responsible for laying bare the argumentation around an understanding of baptism as understood by Karl Barth. T.L. (University of South Africa) contributed towards contextualising the understanding of baptism specifically for the URCSA.

\section{References}

Barth, K., 1959, The Teaching of the Church regarding Baptism, SCM Press, London.

Barth, K., 1981, The Christian life: Church Dogmatics: vol. IV, part 4, Lecture fragments, transl. G.W. Bromiley, Eerdmans, Grand Rapids.

Barth, K., 2004, Church Dogmatics, vol. IV, part 4, T \& T Clark International, London.

Busch, E., 1976, Karl Barth: His life from letters and autographical text, SCM Press, Philadelphia.

Dolamo, R.T.M., 1993, 'The relevance of Karl Barth's theology of church and state for South Africa', doctoral dissertation, Department of Systematic Theology and Theological Ethics, University of South Africa.

Flett, J., 2010, The witness of God: The Trinity, Missio Dei, Karl Barth and the nature of Christian community, Eerdmans, Grand Rapids. PMCid:2887857

Gäbler, U., 1986, Huldrych Zwingli: His life and work, Fortress Press, Philadelphia.

Hunsinger, G., 2000, Disruptive grace: Studies in the theology of Karl Barth, Eerdmans, Grand Rapids.

Luther, M., 1943, Small catechism, Concordia, Missouri.

Mangina, J., 2001, Karl Barth on the Christian life: The practical knowledge of God, Peter Lang, New York.

Mofokeng, T., 1983, The crucified among the cross bearers, J.H. Kok, Kampen.

Schüssler Fiorenza, F. \& Galvin, J. (eds.), 2011, Systematic Theology: Roman Catholic perspectives, vol. 2, Fortress Press, Minneapolis.

Smit, D.J., 1992, 'Reformed theology in South Africa: A story of many stories', Acta Theologica 12(1), 88-110.

Tshaka, R.S., 2010, Confessional Theology? A critical analysis of the theology of Karl Barth and its significance for the Belhar Confession, Cambridge Scholars Publishing, NewCastle. 